\title{
Correction to: Adult Granulosa Cell Tumor of Ovary: Clinical Study of 10 Cases
}

\author{
S. Kayastha ${ }^{1}$ (D) K. Chitrathara ${ }^{1} \cdot$ B. Sigdel ${ }^{1} \cdot$ P. Sanam ${ }^{1} \cdot$ S. Anupama ${ }^{1} \cdot$ A. Remi ${ }^{1} \cdot$ T. Augustine $^{1} \cdot$ \\ B. C. Peter ${ }^{1}$
}

Published online: 3 January 2020

(C) Association of Gynecologic Oncologists of India 2020

\section{Correction to: Indian Journal of Gynecologic Oncology (2020) 18:2 https://doi.org/10. 1007/s40944-019-0343-9}

The article "Adult Granulosa Cell Tumor of Ovary: Clinical Study of 10 Cases," written by S. Kayastha, was originally published electronically on the publisher's Internet portal (currently SpringerLink) on November 15, 2019, with open access. With the author(s) decision to step back from Open Choice, the copyright of the article changed to (c) Association of Gynecologic Oncologists of India 2020 and the article is forthwith distributed under the terms of copyright.

The original article has been corrected.

Publisher's Note Springer Nature remains neutral with regard to jurisdictional claims in published maps and institutional affiliations.

The original article can be found online at https:// doi.org/10.1007/s40944-019-0343-9.

\section{S. Kayastha}

kusmskosuresh1985@gmail.com

1 Department of Surgical and Gynecological Oncology, VPS Lakeshore Global Lifecare, Nettoor, Kochi, Kerala, India 